\title{
Long-term methotrexate efficacy in juvenile localized scleroderma
}

\author{
F Zulian*, C Vallongo, F Vittadello, G Zanon, S Giuliotto, G Martini \\ From 18th Pediatric Rheumatology European Society (PReS) Congress \\ Bruges, Belgium. 14-18 September 2011
}

\section{Background}

Recent studies reported that methotrexate (MTX), appears beneficial in juvenile localized scleroderma (JLS) but little is known about its long-term efficacy. We assessed the long-term efficacy of MTX in a cohort of patients with JLS.

\section{Methods}

We prospectively followed a cohort of patients with JLS who were enrolled in a double-blind, randomized controlled trial. Oral MTX was used at a dose of $15 \mathrm{mg} / \mathrm{m}^{2}$ once a week (max $20 \mathrm{mg}$ ) for at lest 24 months; prednisone $(1 \mathrm{mg} / \mathrm{Kg} /$ day, max $50 \mathrm{mg})$, in a single morning dose for 3 months was added. A target lesion was evaluated clinically, with infrared thermography and using a computerized scoring system with skin score rate (SSR) evaluation. Response to treatment was defined as: no new lesions; SSR $<1$; decrease lesion temperature by at least $10 \%$ compared to baseline. Treatment failure was defined by new lesions, SSR $>1$, or increased lesion temperature. Partial Remission (PR) was defined when the state of responder was maintained $\mathrm{ON}$ treatment for at least 6 months, complete remission (CR) the state of responder OFF treatment for at least 6 months.

\section{Results}

65 patients have been treated with MTX during the open-label phase of the study. Seven patients were lost to follow-up. Of the remaining 58 patients, after a mean follow-up of 43 months (median 36; range 6-72 mesi), $48(82.8 \%)$ were responders, $10(17.2 \%)$ relapsed by 24 months since MTX start. Among the responders, 35 (60.4\%) after a MTX treatment for 27.5 months (median 24, range 18-30) maintained CR for 25 months (median

\footnotetext{
* Correspondence: zulian@pediatria.unipd.it

Rheumatology Unit, Department of Pediatrics, University of Padua, Padua, Italy
}

() 2011 Zulian et al; licensee BioMed Central Ltd. This is an open access article distributed under the terms of the Creative Commons Attribution License (http://creativecommons.org/licenses/by/2.0), which permits unrestricted use, distribution, and reproduction in any medium, provided the original work is properly cited.
24, range 2-48). None of those in CR relapsed. 13 patients $(22.4 \%)$, after a mean follow-up of 20.5 months (median 15.5, range 6-45), were in PR.

\section{Conclusion}

Methotrexate shows a prolonged efficacy in patients with JLS.

Published: 14 September 2011

doi:10.1186/1546-0096-9-S1-016

Cite this article as: Zulian et al:: Long-term methotrexate efficacy in juvenile localized scleroderma. Pediatric Rheumatology 2011 9(Suppl 1): 016.

Submit your next manuscript to BioMed Central and take full advantage of:

- Convenient online submission

- No space constraints or color figure charges

- Immediate publication on acceptance

- Inclusion in PubMed, CAS, Scopus and Google Scholar

- Research which is freely available for redistribution

Submit your manuscript at www.biomedcentral.com/submit
- Thorough peer review

\section{Biomed Central}

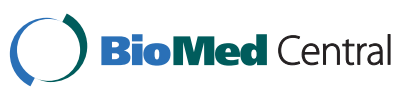

